\title{
SUSTAINABLE VILLAGES
}

\author{
Nada Kosanovic ${ }^{1}$ \\ Suncica Vjestica ${ }^{2}$
}

DOI: https://doi.org/10.31410/LIMEN.2020.399

\begin{abstract}
Despite the fact that we live in a country where the farmers' associations are created among the first on the Old Continent, and where one of the first Institute for Nature Protection is created, statistics warn us that the demise of several hundred Serbian villages and thus the emptying of strategically important areas of the state of Serbia today, is a serious development problem. In this paper an analysis of the rural, age and educational structure of the population, in rural areas of the Republic of Serbia, has been performed. The authors believe that the situation is not hopeless and point out that the sustainable development of the village is possible only if favorable local preconditions for it are met. Therefore, it is necessary to revive and institutionally expand the competencies of rural local communities as a form of local rural self-government in the Serbian folk tradition. Accordingly, decentralization and polycentric development are the main conditions for the renewal of the population and devastated parts of Serbia. Moreover, native networks and integrated rural development are models applicable through LAP in accordance with the characteristics of the area. Nowadays, it is necessary to raise people's awareness of the importance of rural survival and sustainable management of resources in agriculture, i.e. to breathe new life into rural areas, which would also be a motive for staying in the countryside.
\end{abstract}

Keywords: Sustainable village, Status, Development policy, Local communities, Local selfgovernment.

\section{INTRODUCTION}

$\mathrm{T}$ he objective of this research is to indicate on the situation and problems in Serbian villages, using the statistical data. An analysis of the rural, age and educational structure of the population in rural areas of the Republic of Serbia has been performed. At the same time, the authors point out the development possibilities of villages in Serbia and suggest measures and mechanisms for their implementation.

The results of the research show the basic development problems, which are repeatedly reflected in the elements and aspects of further construction and foundation of the existing theory and practice, of the inhabitants ${ }^{3}$ of rural areas, where the authors propose development measures and mechanisms to overcome those problems.

Data sources are: annual publications of the Statistical Office of the Republic of Serbia, relevant bulletins; 2011 Census, Strategy for Agriculture and Rural Development of the Republic of Serbia for the period 2014-2024, Law on Local Self-Government, "Official Gazette of RS", no. 129 of 29 December 2007, 83 of 5 August 2014 - other law, 101 of 16 December

Faculty for Applied Ecology - Futura, Pozeska 83a, 11000 Belgrade, Serbia

Faculty for Applied Ecology - Futura, Pozeska 83a, 11000 Belgrade, Serbia

The term rural in the paper refers to the rural settlements. / Author's note / 
2016 -other law, 47 of June 20, 2018. et al. Other sources, given in the footnotes and bibliography, were also used.

\section{MATERIALS AND METHODOLOGY}

The paper uses research methods and procedures specific to economics and agroeconomics. ${ }^{4}$

By watching, monitoring and observing, a description was made, as an immediate, sensoryperceptual cognition of the subject of research. Using the descriptive analysis, we came to the cognition, findings and descriptions (origin, course and development) of the observed phenomenon (extinction of Serbian villages). The research period is long, considering the fact that the problem which the authors point out is several decades old.

The empirical method, as an important analytical method, was used to process empirical data, using statistics and mathematics. We used the statistical method to collect, present (tables, charts), analyze and interpret numerical data. Furthermore, quantitative research was performed using the mathematical method. In this regard, modeling was applied, where the model is presented as a simplified picture of the observed phenomenon. By modeling, the key parameters of the activities are identified, and these parameters are the basis for the agreement of different activities in the function of reviving Serbian villages.

In addition, general methodological procedures were also applied. By the analytical method, the individual and constituent elements of the observed phenomenon were investigated. The general characteristics of the phenomenon were derived by the synthetic method, whereby the observation of the differences between the important and the irrelevant, the main and the secondary, came to the fore. We performed inductive method for the analysis from the individual to the general. On the other hand, using the deductive method, starting from the general, we analyzed individual properties and elements. Deduction showed how complex the problem of rural extinction in Serbia is. At the end, systematic analysis has indicated the importance of recovery and revitalization of villages in Serbia, in the context of the entire socio-economic system of the Republic of Serbia.

\section{SERBIAN VILLAGES IN THE SYSTEM OF LOCAL SELF-GOVERNMENT ${ }^{5}$}

"Local self-government, in short, is a form of management and decision-making of citizens in local communities. It is in fact the original basic organization of government in a state performed by local authorities. ${ }^{6}$ Local self-government is a form of decision-making and management in local communities, constituted in narrower parts of the state territory, directly by its inhabitants or through their representatives, which they directly elect, as well as other local bodies. It has the status of a constitutional matter, and its independence is guaranteed by

Pejanovic, R. (2007). Some methodological phases and procedures in economy (and agricultural economy). Poljoprivredni fakultet: Letopis naučnih radova, Novi Sad, pp. 174-186

$5 \quad$ The term "local government" was first used by the English philosopher Jeremy Bentham in 1832. The term itself is not clear and precise enough, so the question is what exactly is meant by it. Miodrag Jovicic thought that the term from the Swiss "autonomie locale" and partly the German "gemeinde (kommunal) selbstverwaltung" completely corresponded to "local self-government" in our language. It is narrower than the French term "administration locale", and broader than English "local government" and "local selfgovernment". Stankovic, M. (2015) Local Self-Government in Serbia, Belgrade, 16; Simovic, V. (1966). Communal system and communal policy, Beograd, 41

6 Durdev, A. (2003). Local government. Lokalna samouprava, Novi Sad, 5 
the constitution, which means that it enjoys its protection.". ${ }^{7}$ /Orlovic, P. S., Constitutional Status of Local Self-Government in Serbia, pp.1649-1667/

Regardless of the fact that local self-government has a long tradition as a level of government in Serbia, the status of today's villages is not defined by the Constitution, and villagers are deprived of the right to decide about themselves and the environment in which they live. The constitutional position of local self-government, prescribed by the Constitution, is such that it is guaranteed as a "right of citizens" which "limits state power" (Article 12 of the Constitution of 2006). However, further elaboration of this constitutional starting point has not been completed.

In Serbia, local self-government units are municipalities, cities and the city of Belgrade, as it is written in the Constitution of the Republic of Serbia from 2006 (Article 188), which determines the position of local self-government units. Villages are not defined in the system of local self-government, they do not have a status, budget, source revenues nor competencies.

Local community councils / LCC /, which have been a form of administrational organization in villages since 1963, are a guarantee of further accelerated destruction of villages. According to the Law on Local Self-Government (Official Gazette of the RS, no. 129/2007, 83/2014, $101 / 2016$ and 47/2018.), rural local communities are not seen as the level of government that may have statutory competencies. In terms of the jobs (rural) local communities can perform, and the funds they can get, they are determined by the local self-government unit / LGU / in accordance with the needs of citizens and the possibilities of local communities.

According to the Law on Local Self-Government (Official Gazette of RS, No. 129 of December 29, 2007, 83 of August 5, 2014 - other law, 101 of December 16, 2016 - other law, 47 of June 20,2018. ), local communities and other forms of local self-government are formed in villages, and they can only propose and adopt legally determined jurisdiction and plans, but do not decide on anything, do not have a budget, source revenues nor precise jurisdictions according to the principle of subsidiarity - number of councilors from villages, depending on the number of inhabitants in the villages and the percentage of the population in the municipality to which they belong, as is the case in EU countries. The local community council is the basic representative body of citizens in the area of local self-government. ${ }^{8}$

The act on the establishment of a local community, in accordance with the statute of the municipality or city, determines the activities performed by the local community, local bodies and organization of work of local bodies, decision-making and election procedure of councils and other local self-government bodies, but also protection of rights during elections and other important issues concerning the work of the local community, i.e. another form of local selfgovernment.

By article 74 of the Law on Local Self-Government the competencies of the Local Community Council are defined.

Local community council:

1) adopts the statute of the local community;

2) adopts the financial plan of the local community and develops programs of the local

Markovic, R. (2015) Constitutional Law. Belgrade, pp. 405-406

Law on Local self-government. Official Gazette of the Republic of Serbia, no. 129/2007, 83/2014, 101/2016, $47 / 2018$ 
community;

3) elects and dismisses the president of the local community council;

4) propose measures for the development and improvement of communal and other activities in the area of the local community;

5) adopt rules of procedure for the work of the local community council and other acts within the competence of the local community;

6) initiate the adoption of new or change of existing municipal regulations;

7) perform other tasks within the competence of the local community determined by the statute of the municipality, the act on the establishment of the local community or other municipal regulations. ${ }^{9}$

On June 20, 2018, the National Assembly of the Republic of Serbia adopted the Law on Amendments to the Law on Local Self-Government / LLSG /, whose important changes relate to the introduction of the right of supervision of local self-government bodies over the legality of work and local community acts, which expanded the power of municipality in terms of regulating the framework for the local community. From the above, we can conclude that the revival of Serbian villages is still in line with the illusion of Potemnik, given that the "village is still not deciding about the village".

It can be concluded that, in our recent history, the situation of the rural population has never been so miserable and today this situation is confirmed by statistics and the fact that our villages are getting older and emptier.

The words of wise people, that the peasant is the foundation of the Serbian domestic order, today is both a warning and a signpost for us.

This foundation was destroyed after the Second World War, when migration processes, from villages to towns, took place in Serbia, which resulted in the emptying of the village and the crisis in agriculture that have continued to this day. Confirmation of that are the results of the census of 1948, according to which the agricultural population made up 68 percent of the total population, and in 1991 only 17 percent. The Serbian domestic order is based on a strong village, with a strong large family, and it has been destroyed for the decades, still the fragments of that order are kept by the elderly today.

Ploughland that could feed half of Europe and that fed cattle for export, by which Serbia lived during the time of Milos and Karadjordje, is being turned into pastures and deserted meadows with an area of 505618 ha of uncultivated land in 2012. Out of a total of 4709 settlements, i.e. villages /according to the Constitution, there is no category of villages/ in which lives more than half of the population of Serbia; 1200 of them are in the phase of disappearance. In 1034 of them there are less than 100 inhabitants, mostly middle-aged and older, and 550 of them have less than 50 inhabitants. As many as 500 villages do not have an asphalt road, 400 villages do not have shops, and there are no post offices in 2000 villages. Furthermore, in 230 villages there is no primary school and two thirds of villages do not have an ambulance. In 200 villages there are almost no inhabitants, and also in 200 of them there is no one younger than 25 . It is estimated that in the next 10 years another 700 villages will become empty. Statistics show that in every fourth village, the youngest resident is older than 60 , and according to the data of the SANU Village Committee, as many as 260000 unmarried men are younger than 50 .

9 Law on Local self-government. Official Gazette of the Republic of Serbia, no. 129/2007, 83/2014, 101/2016, $47 / 2018$ 


\section{DEMOGRAPHIC DISCHARGE AND RURAL INDICATORS ${ }^{10}$}

In almost all parts of the Republic of Serbia, especially in the zones which are at a great distance from local, subregional and regional centers, as well as in hilly and mountainous areas, a long period of continuous negative demographic development is present. The consequences of this demographic situation are numerous and multifaceted. From the point of view of the situation in the spatial organization of the settlement network in Serbia, the appearance of spontaneously displaced rural settlements deserves special attention - because it results in spatial-demographic imbalances in the network of settlements in some parts of Serbia, as well as in Serbia as a whole, but also because of the significant disproportions in the degree of socio-economic development and the level of demographic manifestation of settlements in Geospace. /Stamenkovic, S./

In connection with the above, we will list some relevant indicators presented by tabular overview of settlements and populations of central Serbia and Vojvodina in 1991 and 2002. In 1991 the group of the smallest settlements (499 and less inhabitants) included 2373 settlements (50.6\% of the total number of settlements), in which $7.3 \%$ of the population lived. In 2002 the group included 2722 settlements $(57.8 \%)$, in which lived $7.8 \%$ of the total population. Special emphasis should be placed on the representation and growth of demographically dwarf settlements (less than 49 inhabitants), whose number doubled in the observed period: from 180 $(3.8 \%)$ to 346 settlements $(7.4 \%)^{11}$.

Table 1. Settlements of central Serbia and Vojvodina by demographic size in 1991 and $2002^{12}$

\begin{tabular}{|l|c|c|c|c|}
\hline Settlement size & 1991. & 2002. & 1991. & 2002. \\
\hline 1000000 and more inhabitants & 1 & 1 & 1168454 & 1119642 \\
$500000-999999$ inhabitants & - & - & - & - \\
$200000-499999$ inhabitants & - & - & - & - \\
$100000-199999$ inhabitants & 4 & 3 & 602708 & 511502 \\
$50000-99999$ inhabitants & 12 & 14 & 739980 & 902848 \\
$20000-49999$ inhabitants & 26 & 25 & 787388 & 748255 \\
$10000-19999$ inhabitants & 42 & 42 & 598477 & 615941 \\
$5000-9999$ inhabitants & 96 & 95 & 650968 & 657269 \\
$2000-4999$ inhabitants & 334 & 309 & 1005285 & 930159 \\
$1000-1999$ inhabitants & 675 & 544 & 935500 & 750303 \\
$500-999$ inhabitants & 1080 & 951 & 765274 & 676843 \\
$200-499$ inhabitants & 1350 & 1335 & 453371 & 449165 \\
$50-199$ inhabitants & 843 & 1041 & 109985 & 126604 \\
49 and less inhabitants & 180 & 346 & 5405 & 9470 \\
\hline Total & 4693 & 4706 & 7822795 & 7498001 \\
\hline
\end{tabular}

From this data, we can see the appearance of demographic fragmentation of settlements as a consequence of population decline, population aging, etc.

10 At the local level, the OECD defines rural areas according to population density. Rural settlements are considered to be settlements with a population density below 150 inhabitants per $\mathrm{km} 2$. According to that classification, $85 \%$ of the territory of the Republic of Serbia is considered rural.

11 Stamenković, S. (2004) Some actual questions of the spatial organization of the network of settlements and the relevant demography problems in Serbia. Demografija, Beograd

12 Documentation material by the Statistical Office of the Republic of Serbia 
Follow-up, the table presents demographic indicators of rural areas of the Republic of Serbia, data on the estimated movement of the population of the Republic of Serbia, educational structure of the population older than 15 in rural areas, unemployment in rural areas, age structure and rural infrastructure. By analyzing the data, we got the information necessary for modeling the revival of villages in Serbia in the context of the entire socio-economic system, i.e. the economic system of the Republic of Serbia.

Table 2. Demographic indicators of rural areas of the Republic of Serbia

\begin{tabular}{|l|l|l|}
\hline Indicators & Serbia & Rural Areas \\
\hline Geographical indicators & & \\
\hline Area $/ \mathrm{km}^{2} /$ & 88499 & 69040 \\
\hline Number of settlements & 6158 & 5965 \\
\hline Demographic indicators & & \\
\hline Population (Census 2002) & 7498001 & 3279522 \\
\hline Population (Census 2011) & 7186862 & 2914990 \\
\hline Population density (inhabitants / $\left.\mathrm{km}^{2}\right)$ & 9.3 & 6.2 \\
\hline Share of population younger than $15(\%)$ & 14.3 & 13.9 \\
\hline $\begin{array}{l}\text { Share of the population older than } 65 \\
\text { years (\%) }\end{array}$ & 17.4 & 20.2 \\
\hline Ageing index & 1.2 & 1.4 \\
\hline
\end{tabular}

Source: 2011 Census of Population of the Republic of Serbia

Table 3. Movement of the estimated number of inhabitants of the Republic of Serbia in the period 2012-2018.

\begin{tabular}{|c|r|r|r|r|r|r|}
\hline $\begin{array}{c}\text { Estimated population } \\
\text { number (average } \\
\text { annual rate) }\end{array}$ & $\begin{array}{c}\text { Republic of } \\
\text { Serbia }\end{array}$ & $\begin{array}{c}\text { Region of } \\
\text { Belgrade }\end{array}$ & $\begin{array}{c}\text { Region of } \\
\text { Vojvodina }\end{array}$ & $\begin{array}{c}\text { Region of } \\
\text { Sumadija } \\
\text { and Western } \\
\text { Serbia }\end{array}$ & $\begin{array}{c}\text { Region of } \\
\text { South and } \\
\text { Eastern } \\
\text { Serbia }\end{array}$ & $\begin{array}{c}\text { Region of } \\
\text { Kosovo } \\
\text { and } \\
\text { Metohija }\end{array}$ \\
\hline 2002 & 7500031 & 1578364 & 2034851 & 2135393 & 1751423 & - \\
\hline 2011 & 7236519 & 1658151 & 1932945 & 2033203 & 1612220 & - \\
\hline 2016 & 7058322 & 1683962 & 1881357 & 1956786 & 1536217 & - \\
\hline 2017 & 7020858 & 1687132 & 1871515 & 1941130 & 1521081 & - \\
\hline 2018 & 6982604 & 1690193 & 1861863 & 1924816 & 1505732 & \\
\hline
\end{tabular}

Over 2002-2018, the number of populations in the Republic of Serbia was continuously declining. At the regional level, only the Region of Belgrade recorded population growth, while the most pronounced decline was recorded in the Region of Southern and Eastern Serbia. Statistical Office of the Republic of Serbia published the data of the number of live births in the Republic of Serbia, which in 2016 was 64 734, while the number of deaths was 100834. In that year alone, the negative natural increase was 36 100. In the period 2006-2016, the number of inhabitants in RS was reduced by about 385000 only on the basis of natural increase. Of the total number of municipalities /169/ in the Republic of Serbia, the rate of natural increase in 2016 was positive in only five municipalities: Sjenica, Novi Sad, Presevo, Tutin and Novi Pazar. 
Unfavorable demographic trends also result in an unfavorable educational structure of the rural labor force, which does not meet the requirements of the labor market, therefore the quality of the labor force is one of the limiting factors of economic development of rural areas. At the same time, the educated population finds it difficult to stay in rural areas without satisfactory transport and communal infrastructure.

According to the 2011 census of the Republic of Serbia, the educational structure of the population older than 15 years is dominated by persons with completed secondary school (42.4\% in rural areas), which is a significantly higher percent compared to the participation of persons with completed primary school $(27.7 \%)$ and those without formal education $(23.4 \%)$. The structure of the real labor force in rural areas does not respond to the requirements of the modern labor market. The reason for that is the lower percent of highly educated population in these areas, compared to the national average $(6.1 \%: 16.2 \%)$, and that is one of the important limiting factors of economic development of these areas. Households whose main activity is agriculture are characterized by a lower share of educated members and lower unemployment (here we are talking about the hidden unemployment, i.e. unpaid helping household members).

Table 4. Educational structure of the population older than 15 years in rural areas

\begin{tabular}{|l|l|l|}
\hline $\begin{array}{l}\text { \% without formal } \\
\text { education }\end{array}$ & $\begin{array}{l}13.7 \% \\
\text { With share of } 80.4 \% \text { with } \\
\text { incomplete primary education. }\end{array}$ & $\begin{array}{l}23.4 \% \\
\text { With share of } 81.2 \% \text { with incomplete } \\
\text { primary education }\end{array}$ \\
\hline$\%$ primary school & $20.8 \%$ & $27.7 \%$ \\
\hline$\%$ high school & $48.9 \%$ & $42.4 \%$ \\
\hline $\begin{array}{l}\% \text { highly educated } \\
\text { population }\end{array}$ & $\begin{array}{l}16.2 \% \\
\text { With share of } 65.2 \% \text { with } \\
\text { Bachelor's degree }\end{array}$ & $\begin{array}{l}6.1 \% \\
\text { With share of } 51.8 \% \text { with } \\
\text { Bachelor's degree }\end{array}$ \\
\hline$\%$ unknown & $0.4 \%$ & $0.4 \%$ \\
\hline
\end{tabular}

Source: SORS (processed by The Ministry of Agriculture, Forestry and Water Economy of the Republic of Serbia), * According to SORS criteria

Table 5. Unemployment in rural areas

\begin{tabular}{|c|c|c|c|c|c|c|c|c|c|c|c|}
\hline Type of settlement & 2006 & 2007 & 2008 & 2009 & 2010 & 2011 & 2012 & 2013 & 2014 & 2015 & 2016 \\
\hline \multicolumn{12}{|c|}{ Employment rate (\%) } \\
\hline Serbia & 49.8 & 51.5 & 53.7 & 50.4 & 47.2 & 45.4 & 45.4 & 47.5 & 50,4 & 52,0 & 55,2 \\
\hline Urban settlements & 49.1 & 50.8 & 50.7 & 47.9 & 45.4 & 43.9 & 43.4 & 45.7 & 49,2 & 53,5 & 53,5 \\
\hline Other settlements & 51.0 & 52.4 & 58.1 & 54.0 & 49.8 & 47.4 & 47.9 & 50.2 & 52,3 & 57,8 & 57,8 \\
\hline \multicolumn{12}{|c|}{ Unemployment rate $(\%)$} \\
\hline Serbia & 20.9 & 18.1 & 13.6 & 16.1 & 19.2 & 23.0 & 23.9 & 23.0 & 20,1 & 18,2 & 15,9 \\
\hline Urban settlements & 22.0 & 18.6 & 15.9 & 18.4 & 21.4 & 24.8 & 26.9 & 25.0 & 21,6 & 17,9 & 17,9 \\
\hline Other settlements & 19.4 & 17.3 & 10.8 & 13.3 & 16.4 & 20.6 & 20.1 & 19.9 & 17,9 & 12,9 & 12,9 \\
\hline
\end{tabular}

Source: SORS (processed by The Ministry of Agriculture, Forestry and Water Economy of the Republic of Serbia), * According to SORS criteria

Although the rural economy has a high unemployment rate, in recent years this indicator has stabilized at around $20 \%$. The unemployment rate in rural areas is still high, with a particularly pronounced share of younger categories of the unemployed rural population. 
The youngest and oldest categories of the rural population have an evidently higher share in total employment, compared to the same categories of the urban employed population. The participation of women in formal employment in rural areas is generally at the lower level compared to urban areas. Regionally speaking, the most unfavorable position of women ${ }^{13}$ according to labor market indicators is in the region of Southern and Eastern Serbia. All age categories of women in rural areas participate in the total employment with about $39 \%$, while this participation of women in urban areas is around $44 \%$.

Table 6. Rural infrastructure

\begin{tabular}{|c|c|c|c|c|}
\hline $\begin{array}{c}\text { General data by regions, } \\
\text { 2016 Region }\end{array}$ & Area $\left(\mathrm{km}^{2}\right)$ & Number of settlements & Population & \\
\hline Republic of Serbia, In total & 88499 & & In total & per $\mathrm{km}^{2}$ \\
\hline Region of Belgrade & 3234 & 157 & 7058322 & \\
\hline Region of Vojvodina & 21614 & 467 & 1881357 & 87 \\
\hline $\begin{array}{c}\text { Region of Sumadija and Western } \\
\text { Serbia }\end{array}$ & 26493 & 2112 & 1956786 & 74 \\
\hline $\begin{array}{c}\text { Region of South and Eastern } \\
\text { Serbia }\end{array}$ & 26248 & 1973 & 1536217 & 59 \\
\hline Region of Kosovo and Metohija & 10910 & 1449 & $\ldots$ & $\ldots$ \\
\hline
\end{tabular}

Source: SORS (processed by The Ministry of Agriculture, Forestry and Water Economy of the Republic of Serbia), * According to SORS criteria

Rural infrastructure in the Republic of Serbia is underdeveloped. Rural area is characterized by low roads infrastructure, communal infrastructure and other important elements of living standards. Infrastructure at the municipal level is more or less developed, with huge potential for further development, but also with great limitations such as poor information on the needs, characteristics and benefits of rural infrastructure, which contributes to unresolved water supply, telecommunications and other obstacles to development.

13 The total number of women who live in villages is 1.6 billion and they make up one quarter of the world's total population. World data indicates that women in rural areas own only $2 \%$ of the land and earn only $1 \%$ of all agricultural income, which shows us the extremely difficult position they are in. Gender inequality in the countryside, in Serbia, does not deviate much from world statistics. The largest part of the informally engaged labor force in performing agricultural work in RS make women, with a share of about $63 \%$. Futhermore, there is a low share of women who are farm owners, i.e. on whose behalf the farm operates (only about 17\%), and an even lower share of them as farm managers, i.e. those who make decisions about the organization of agricultural production on the farm (16\%) and permanent employees on the farm $(14.8 \%)$. Women who live in the household are usually not the owners of the houses in which they live, they do not own land, nor the means of production. A survey by the Institute for Gender Equality showed that women who live in villages, in $61 \%$ of cases do not own or co-own a house, which is certainly due to patriarchal patterns of inheritance of parents' property in which female heirs renounce their right to inheritance. The position of older women in the countryside is far more difficult than that of working age, and it is especially more difficult than the position of women living in urban areas. Although $50 \%$ of women in the village are older than 65 , grandmothers in the villages very rarely own property - to be precise only $9.1 \%$ of them. $88.5 \%$ live and work on their husband's property, while in $2.4 \%$ of cases the property is shared. 


\section{ORGANIZATIONS OF THE NETWORK OF RURAL SETTLEMENTS - NATIVE NETWORKS}

Rural settlements in Serbia were formed spontaneously, often by chaotic concentration on randomly populated areas. Nowadays, the network of rural settlements is changing, some villages are already extinguished, others are empty (dying villages), some are still sustainable (sustainable villages), while some, which are located in prosperous areas and close to the big cities, are developed. Among them, there are several villages that could serve as a prototype of successful, agrarian and rural development for our specific global circumstances which are fundamentally unfavorable. Therefore, it is necessary for each type of village to find a specific development model that would be optimal for it. The most urgent measures need to be taken in the dying villages as well as those that are still sustainable. It is very difficult to determine, with statistical reliability, which village is sustainable and which is not. However, it is much more likely that a village with more than 500 inhabitants will develop and last longer, than the one with less than 200 inhabitants, and in this category (villages with more than 500 inhabitants) the largest number in 2002 in Serbia was 951 villages and in 2011 - 2832 villages! Scientists who deal with the sociology of villages claim that the disappearing villages are those with less than 100 inhabitants, and in Serbia in 2011 there were 1043 of them! Also, many villages with less than 200 inhabitants, if they are left without children and young women who still want to give birth, can be joined to this statistics.

This refers to villages that are infrastructurally neglected, economically devastated and obsoleted, precisely those in the Region of Southern and Eastern Serbia where we have the lowest population rate of 59 inhabitants per $\mathrm{km}^{2}$. When observed together extinguished and dying villages it can be seen that a quarter of the total number of settlements has disappeared, and in Serbia there are 4709 of them. For these villages, virtual rural municipalities should be formed, and for all the other villages native communication networks. Moreover, electronic means of communication are necessary for the inclusion of a large number of successful people from the Serbian diaspora, who want to be included and have important tasks in strategies, plans and projects of local, regional and national development. In that way, connections and relations of the Serbian diaspora with the Republic of Serbia would be institutionalized. If they are already leaving the country, these ties would create an opportunity for Serbia not to lose them completely and for them also not to lose Serbia.

\section{INTEGRATED RURAL DEVELOPMENT}

The biological extinction of the nation demands that we turn to the countryside. Instead of the current approach to the agriculture, where farmers are treated as producers of cheap food, it is necessary to introduce the concept of integrated rural development, which will be based on demographic, natural, economic and socio-cultural potentials. The concept of integrated rural development is based on the comprehensive development of rural mixed residential areas in which almost half of the population of Serbia lives. The policy of relying on agriculture and rural economy should not only be in the function of temporarily survival, but also in the function of the permanent commitment of Serbia and its economic development policy. This should be based on decentralization and balanced economic development that would bring back life to the Serbian village. The state should support this development concept and create mechanisms for maximum exploitation of opportunities, that come through EU funds. Accordingly, it is important to encourage the administration to adapt to the EU planning and implementation system for the development of rural areas, but also to encourage the rural population to use those measures. 
At the same time, small agricultural holdings, whose number is declining every year, need to be organized into agricultural cooperatives and associations. Therefore, commercial family farms and cooperatives must have a unique, integrated, and modernized product procurement and sales system. The state needs to create a Center for Support of Agricultural Cooperatives and solve the problem of ownership over the property of cooperatives. Also, rural development programs should be focused on training farmers to use new technologies in restructured agricultural production, thus contributing to the reduction of the isolation of the most important regions and putting emphasis on the local conditions and opportunities. Thanks to such programs, the inhabitants of these areas are given the chance to engage in other activities besides the agriculture, such as forestry, crafts, construction of small processing facilities, greenhouse flowers production, vegetables, tourism. The diversification of the economy both at the level of the village and at the level of small agricultural holdings will enable the inhabitants of the village to become entrepreneurs. The role of the state, in order to rebuild and revitalize the village is directly related to the general economic development policy and the environments created by the state. The best long-term strategy is not to develop comparative, but competitive advantages. Stronger appearance of brand products on the market implies a strategic concept of development of export-oriented agriculture, but also improving the competitiveness of agricultural products, raising product quality, creating and promoting Serbian brands: Arilje raspberries, Pozega plums, Homolje honey, Srem sausages, ham and bacon, Sjenica cheese, Uzice beef prosciutto, Uzice bacon, Rtanj tea, Krivovir cheese, Homolje sheep cheese, Kladovo caviar, Serbian Slivovitz, etc. This is definitely the right way to revive Serbian villages and agriculture. At first glance, the implementation of some of these measures may seem daunting, regarding the fact that significant resources and a long period of time are required, but this should not be the reason to delay the beginning of their implementation.

\section{CONCLUSION}

The legal academic profession and science believe that real local self-government exists if three conditions are met. The first is that the local population elects its representative bodies that directly or through their executive bodies have "certain decisive rights". The second is that these bodies have their financial and local jurisdiction, i.e. to perform a certain range of tasks on their territory as a government. Third, that the jurisdiction of local authorities really and formally affects the life and development of the local community. ${ }^{14}$

Nowadays, situation does not testify in favor of the above, since the political role of local selfgovernment is obviously weak, which is confirmed by the data presented in the previous part of the paper. So, it can be concluded that the village is still not deciding about the village, due to the fact that the villagers do not have the authority, financial resources nor the ability to directly influence the personnel policy. So, what awaits us in the future?

Despite the legislative framework and the general sympathies of the social community for the village and rural development, the rural environment is still not developing. Older people who left the villages in the 1960s and 1970s are returning to rural areas, and besides them you can also find some enthusiasts, lovers of nature and healthy living who return there.

Rural areas are marginalized by local decision makers, both in local development planning and in the implementation of potential measures. The statistics show that the method of realization of policy makers intended for the end users, and based on the principle "bottom-down" did not 
give the expected results. Therefore, it is necessary to introduce decision-making at the local level using "bottom-up" model, i.e. to include all those to whom the defined development guidelines apply. ${ }^{15}$

In addition, the most vivid answer for bringing life back to dying Serbian villages and supporting more balanced regional development would be a quote of the great military leader: "One can rule well from a distance but only one can manage well from close ${ }^{16}$."

\section{REFERENCES}

Census of Agriculture (2011). Official Gazette of the Republic of Serbia

Đurđev, A. (2003). Lokalna samouprava [Local government]. Lokalna samouprava, Novi Sad, 5.

Government of the Republic of Serbia (2007). Zakon o lokalnoj samoupravi. [Law on Local self-government]. Official Gazette of the Republic of Serbia, no. 129/2007, 83/2014, 101/2016, 47/2018.

Government of the Republic of Serbia (2014). Strategija poljoprivrede i ruralnog razvoja Republike Srbije za period 2014-2024. godine [Strategy for Agriculture and Rural Development of the Republic of Serbia for the period 2014-2024]. Official Gazette RS, no. $85 / 2014$

Orlović, P. S. (2015). Ustavopravni položaj lokalne samouprave u Srbiji [Constitutional Status of Local Self-Government in Serbia]. Zbornik radova pravnog fakulteta, Novi Sad, 16491667

Pejanović, R. (2007). O nekim metodološkim fazama $i$ postupcima u ekonomiji (i agroekonomiji) [Some methodological phases and procedures in economy (and agricultural economy)]. Poljoprivredni fakultet: Letopis naučnih radova, Novi Sad, 174186

Simović, V. (1966) Komunalni sistem i komunalna politika [Communal system and communal policy]. Naučna knjiga, Beograd, 41

Stamenković, S. (2004) Neka aktuelna pitanja prostorne organizacije mreže naselja $i$ relevantni demografski problemi u Srbiji [Some actual questions of the spatial organization of the network of settlements and the relevant demography problems in Serbia]. Demografija, Beograd

Stanković, M. (2015). Lokalna samouprava u Srbiji [Local government in Serbia]. Pravni fakultet Univerziteta u Beogradu, Beograd, vol. 16

\footnotetext{
15 Branislav, M. Rural development - a practicum for locals. /www.skgo.org/

16 Napoleon Bonaparte
} 